\title{
Corticotropin-releasing Factor: Long-lasting Facilitation of the Acoustic Startle Reflex
}

\author{
K. C. Liang, K. R. Melia, M. J. D. Miserendino, W. A. Falls, S. Campeau, and M. Davis \\ Ribicoff Research Facilities of the Connecticut Mental Health Center, Department of Psychiatry, Yale University School of \\ Medicine, New Haven, Connecticut 06508
}

Intracerebroventricular infusion of corticotropin-releasing factor (CRF) (0.1-1.0 $\mu \mathrm{g})$ produced a pronounced, dosedependent enhancement of the acoustic startle reflex in rats. This excitatory effect began about 20-30 min after infusion, grew steadily over the $2 \mathrm{hr}$ test period, and lasted at least $6 \mathrm{hr}$. Higher doses of CRF (10 $\mu \mathrm{g})$ often produced marked facilitation and then inhibition of startle that oscillated repeatedly with a period of 10-20 min. CRF-enhanced startle did not result from an increase in sensitization produced by repetition of the startle stimulus or from a blockade of habituation. Peripheral injections of the autonomic ganglionic blockers hexamethonium (10 $\mathrm{mg} / \mathrm{kg}$ ) or chlorisondamine ( 3 $\mathrm{mg} / \mathrm{kg}$ ) slightly attenuated the magnitude of CRF-enhanced startle, suggesting a partial role of peripheral sympathetic activation. Intracerebroventricular infusion of the CRF antagonist $\alpha$-helical CRF ${ }_{9-41}$ ( $\alpha$ hCRF; 25 or $50 \mu \mathrm{g}$ ) blocked CRFenhanced startle when infused 5 min prior to CRF, indicating a central site of action. CRF-enhanced startle also was reversed when $\alpha$ hCRF was given $\mathbf{9 0}$ min after infusion of CRF. This suggests that exogenously applied CRF remains in the brain for a very long time after administration or that CRF given exogenously initiates a process that results in a longlasting activation of endogenous CRF. Because the startle reflex is elevated by both conditioned and unconditioned fear, these data lend further support to the idea that CRF infusion produces a behavioral state that resembles fear or anxiety. Because startle is mediated by a well-defined neural pathway, CRF-enhanced startle may provide a useful behavioral assay to analyze the neural systems upon which exogenous CRF acts to produce its behavioral effects.

Corticotropin-releasing factor (CRF), a 41 amino acid peptide that regulates the release of adrenocorticotropin from the anterior pituitary (Vale et al., 1981), has been implicated in many neural and behavioral functions in addition to its hypophysiotropic effect (cf. Dunn and Berridge, 1990). Anatomically, CRF-

\footnotetext{
Received Sept. 20, 1991; revised Jan. 14, 1992; accepted Jan. 15, 1992.

This research was supported by NIMH Grants MH-25642 and MH-47840, NINCDS Grant NS-18033, Research Scientist Development Award MH-00004, a grant from the Air Force Office of Scientific Research, and the State of Connecticut. W.A.F. and M.J.D.M. were supported by NIMH Training Grant MH18397. K.C.L. was a visiting scholar sponsored by the National Science Council of the Republic of China. We extend our sincere thanks to Lee Schlesinger, who tested some of the animals used for these studics, and to Leslic Ficlds for help in typing the manuscript.

Correspondence should be addressed to Dr. Michael Davis, Ribicoff Research Facilities of the Connecticut Mental Health Center, Department of Psychiatry, Yale University School of Medicine, 34 Park Street, New Haven, CT 06508.

Copyright (c) 1992 Society for Neuroscience $0270-6474 / 92 / 122303-10 \$ 05.00 / 0$
}

immunoreactive cells and terminals are distributed widely throughout the CNS (Cummings et al., 1983; Joseph and Knigge, 1983; Swanson et al., 1983; Fellman et al., 1984; Merchenthaler, 1984; Skofitsch and Jacobowitz, 1985; Sakanaka et al., 1986; Foote and Cha, 1988). CRF binding sites are also located in many brain regions ranging from the cerebral cortex to the spinal cord (DeSouza et al., 1985; DeSouza, 1987). Central administration of CRF causes a wide spectrum of physiological effects similar to those produced by stressful stimuli, which are independent of its pituitary-adrenal activating property (c.. Dunn and Berridge, 1990). These include increased firing of locus coeruleus neurons (Valentino and Foote, 1987, 1988), altered forebrain norepinephrine and dopamine turnover (Dunn and Berridge, 1987; Matsuzaki et al., 1989; Butler et al., 1990), elevated release of GABA in the striatum (Sirinathsinghji and Heavens, 1989), changes in respiration (Bohmer et al., 1990), inhibition of gastric acid secretion (Tache et al., 1983), and increased peripheral sympathetic outflow (Brown et al., 1982; Brown, 1986; Grosskrevtz and Brody, 1988; Stephens et al., 1988).

Intracerebroventricular (icv) infusion of CRF produces a constellation of behavioral responses also similar to those seen during periods of stress or fear. These include increased grooming (Britton et al., 1982; Veldhuis and DeWied, 1984; Dunn et al., 1987), changes in exploratory or locomotor behavior consistent with those produced by stress (Britton et al., 1982; Sutton et al., 1982; Berridge and Dunn, 1989; Spadaro et al., 1990), inhibition of feeding (Krahn et al., 1988), disruption of sexual behavior (Rivier et al., 1986), response suppression in the operant conflict test (Britton et al., 1985; Cole and Koob, 1988), decreased social interaction (Dunn and File, 1987), defensive withdrawal (Takahashi et al., 1989; Yang and Dunn, 1990; Yang et al., 1990), and facilitation of amphetamine-induced stereotyped behavior (Cole and Koob, 1989). These findings have led to the suggestion that release of CRF may mediate many of the physiological and behavioral effects observed during stress or fear (Koob and Bloom, 1985; Fisher, 1989). This suggestion is further supported by the findings that CRF immunoreactivity or mRNA levels in certain brain regions are altered by acute or chronic stress (Chappell et al., 1986; Haas and George, 1988; Imaki et al., 1991) and that many effects of stress can be blocked by icv or local brain infusion of the CRF antagonist $\alpha$-helical $\mathrm{CRF}_{9-41}(\alpha$ hCRF; Brown et al., 1985; Britton et al., 1986; Berridge and Dunn, 1987, 1989; Kalin et al., 1988; Shibasaki et al., 1988; Stephens et al., 1988; Takahashi et al., 1989, 1990; Winslow et al., 1989; Cole et al., 1990; Rivest and Richard, 1990; Baldwin et al., 1991; Melia and Duman, 1991). In addition, several recent studies have found that infusion of CRF 
into localized brain regions affects fear-motivated bchaviors (Krahn et al., 1988; Liang and Lee, 1988; Lee and Tsai, 1989; Butler et al., 1990).

The acoustic startle reflex is a short-latency response of the skeletal musculature elicited by a sudden auditory stimulus. Previous studies have shown that this reflex can be modulated by stress, fear, or other negative affective states. For example, in animals startle is potentiated by a series of brief footshocks (Davis, 1989) or by a cue previously paired with footshock (Brown et al., 1951; Davis and Astrachan, 1978). Moreover, this latter effect can be attenuated by anxiolytic drugs and increased by anxiogenic compounds (cf. Davis, 1986). In humans, startle can be elevated by anticipation of electric shock (Grillon et al., 1991) or by presentation or imagery of negatively affective situations (cf. Lang et al., 1990). CRF has been found to enhance acoustic startle amplitude in rats when injected icv, and this effect is attenuated by the anxiolytic drug chlordiazepoxide (Swerdlow et al., 1986). In addition, the CRF antagonist $\alpha$ hCRF was reported to attenuate CRF-enhanced startle as well as fear potentiation of the startle response (Swerdlow et al., 1989).

In a series of exploratory studies, we confirmed that CRF can markedly increase the amplitude of the acoustic startle reflex. However, the magnitude and time course differed considerably from that previously reported. The facilitatory eflect did not appear until approximately 20-30 min after icv infusion, was very large, and persisted for many hours. The present series of experiments sought to characterize this finding more fully. The effects of icv CRF on habituation and sensitization were tested because some drugs can alter startle by affecting habituation or sensitization produced by repetition of the startle eliciting stimulus (cf. Davis, 1980). Because of the prominent influences of icv CRF on the sympathetic nervous system (Brown et al., 1982), and the finding that the peripheral sympathetic activation may contribute to CRF-induced alterations in grooming, locomotion, and eating (Britton and Indyk, 1989), the effect of icv CRF in animals pretreated with the autonomic ganglionic blockers hexamethonium or chlorisondamine was examined. The ability of pretreatment with the CRF antagonist $\alpha$ hCRF to block CRFenhanced startle was also tested. Finally, because CRF-enhanced startle lasted for over $2 \mathrm{hr}$, at a time when CRF given icv might no longer be in the brain, the ability of $\alpha$ hCRF to reverse CRF-enhanced startle was tested when the antagonist was given 90 min after CRF infusion.

\section{Materials and Methods}

\section{Animals}

Male Sprague-Dawley rats (Charles River, Kingston, NY) weighing 280 $340 \mathrm{gm}$ were used. They were housed in groups of three or four prior to surgery and were maintained on a $12 \mathrm{hr} / 12 \mathrm{hr}$ light/dark schedule (lights on at 7:00 A.M.) with food and water continuously available throughout the study. They were housed singly following surgery in 20 $\times 24 \times 36 \mathrm{~cm}$ wire mesh cages.

\section{Surgery and histology}

Two to three weeks after the rats arrived from the supplier, icv cannulas were implanted. For all implants, rats were anesthetized with chloral hydrate $(400 \mathrm{mg} / \mathrm{kg}$ ) and positioned in a stereotaxic instrument. Animals were individually housed after surgery and allowed at least 1 week for recovery.

Intracerebroventricular cannula implantation. Methods for design and implantation of icv cannulas were described previously (Kehne et al., 1981). Cannulas were implanted into the left or right lateral ventricle (coordinates relative to bregma: $0.0 \mathrm{~mm}$ anterior, $1.2 \mathrm{~mm}$ lateral to the midline, 3.5-4.5 mm below the dura; Paxinos and Watson, 1986). The icv cannula was constructed of a 26-gauge stainless steel tube $(1 \mathrm{~cm}$ long) partially inserted into a $5 \mathrm{~cm}$ piece of PE-20 tubing, which had a void volume of approximately $5 \mu \mathrm{l}$. It was affixed to the skull using jeweler's screws with fast-drying Loctite adhesive.

At the completion of each experiment, placement of cannulas was verified by injecting $10 \mu \mathrm{l}$ of methylene blue dye through the cannula. Cannulas were judged to be properly located if the dye was clearly evident throughout at least one ventricle and the aqueduct of Sylvius.

\section{Apparatus}

Startle responses were measured in five identical stabilimeter cages described previously (Cassella and Davis, 1986). Each stabilimeter was constructed of Plexiglas and wire mesh $(9 \times 15 \times 15 \mathrm{~cm})$ and suspended within a steel frame between compression springs and an accelerometer. Cage movement resulting from a startle response was transduced by the accelerometer into a voltage that was proportional to the displacement velocity. Startle amplitude was defined as the maximum accelerometer voltage during the first $200 \mathrm{msec}$ following the startle stimulus onset. The voltage was measured and recorded with a specially designed circuit (Weiss and Davis, 1976) interfaced to a PDP-11 or a Macintosh II microcomputer.

The five stabilimeters were housed in a ventilated, sound-attenuating chamber lighted by a fluorescent bulb. Each cage was located $10 \mathrm{~cm}$ from a high-frequency speaker (Radio Shack Supertweeter) that delivered the startle-eliciting stimuli (a $50 \mathrm{msec}$ burst of white noise having a rise/decay time of $5 \mathrm{msec}$ and variable intensity from $95-115 \mathrm{~dB}$ ). A white noise generator (Grason-Stadler, model 901B) provided $55 \mathrm{~dB}$ background white noise. Sound measurements were made within the cages using a General Radio model 1551-C sound level meter (A scale).

\section{Matching}

One to two weeks following surgery, rats were presented with 30 noise bursts at an interstimulus interval of $30 \mathrm{sec}, 5 \mathrm{~min}$ after they were placed into the test cages. Stimulus intensities were 95,105 , and $115 \mathrm{~dB}$, with 10 noise bursts at each intensity presented in a balanced order across the session. The mean startle amplitude across the 30 stimuli was used to divide rats into groups with similar mean startle amplitudes.

\section{Test procedure and drug administration}

Startle was tested 1 or $2 \mathrm{~d}$ after matching. Rats were placed into the startle cages and, after a $5 \mathrm{~min}$ preperiod, were presented with 300 bursts of $105 \mathrm{~dB}, 50 \mathrm{msec}$ white noise. The interstimulus interval was $30 \mathrm{sec}$. Drug infusions occurred immediately after presentation of the 60 th stimulus such that 240 stimuli were presented during the $120 \mathrm{~min}$ postinfusion period.

In the dose-response studies infusions were given remotely without interrupting the progress of stimulus presentation. A $2 \mathrm{~m}$ length of PE20 tubing extended from a $10 \mu$ l Hamilton microsyringe mounted on a IIarvard infusion pump (Model 975) outside the chamber, into the startle cage where it connected to the cannula. This PE-20 tubing was filled with distilled water. Five microliters of drug solution plus $8 \mu \mathrm{l}$ of artificial cerebrospinal fluid (ACSF) were drawn into the PE-20 tubing at the cannula end. Different solutions were separated by small air bubbles. At the cannula end of the long tubing, a portion of the tubing formed a coil, which provided elasticity to allow the animal free movement in the stabilimeter. The rate of infusion was $2.5 \mu \mathrm{l} / \mathrm{min}$.

\section{Data analysis}

For each animal, the 300 startle scores were collapsed into 30 blocks of 5 min each, with the mean score of each block designated as the raw startle score. A preinfusion mean baseline startle score was computed by taking the mean startle amplitude across the 20 startle stimuli presented during the last $10 \mathrm{~min}$ of the $30 \mathrm{~min}$ preinfusion period. This block of time was chosen because startle amplitudes generally habituate to a reasonably stable asymptotic level within $20 \mathrm{~min}$. To reflect the effect of infusion (drug or vehicle), a change score was derived by subtracting the preinfusion mean baseline startle score from each raw startle score obtained after infusion. This startle change score was used for data analysis and presentation. To evaluate the drug effects statistically, the mean change scores for four 20 min periods $(11-30,41-60,71-90$, and 101-120 min after drug infusions) were calculated to represent the effects of drugs or vehicle infusion at periods $1-4$ after infusion. 


\section{Specific procedures}

Dose-response effects of icv CRF on startle amplitude (experiment 1). To evaluate the effects of various doses of icv CRF on startle, icv cannulas were implanted in 21 rats, which were then tested for startle as previously described. They were divided into four groups, each of which reccived $5 \mu$ l of either ACSF $(n=6)$ or $0.1(n=5), 0.5(n=5)$, or $1.0(n=5) \mu \mathrm{g}$ of CRF (human/rat CRF, Penninsula Laboratory) dissolved in $5 \mu \mathrm{l}$ of ACSF. Because Swerdlow et al. (1986) reported that $10 \mu \mathrm{g}$ of CRF actually had a smaller effect on startle than $1 \mu \mathrm{g}, 10$ more rats were tested after icv infusion of either ACSF or $10 \mu \mathrm{g} \mathrm{CRF}$, using a crossover design in which half the animals were first tested with ACSF and then $2 \mathrm{~d}$ later with CRF and vice versa.

The interaction between icv CRF-enhanced startle and stimulus repetition (experiment 2). Previous studies have shown that some drugs can alter startle by affecting habituation or sensitization (cf. Davis, 1980). To evaluate whether the effects of CRF on startle are dependent upon repetitive presentation of auditory stimuli, 10 rats were given the usual 30 min preinfusion baseline test, infused with either $1 \mu \mathrm{g} C R F$ or ACSF, and then returned to the colony room. Sixty minutes later they wcrc returncd to the test cages and tested for startle over the next $2 \mathrm{hr}$ in the usual way. Two to three days later these procedures were repeated except rats previously given CRF were now given ACSF and vice versa. Finally, the five rats that were infused with CRF on day 2 were given three more tests, each consisting of 60 startle stimuli presented at a 30 sec interstimulus interval, beginning 4,6 , and $24 \mathrm{hr}$ after their CRF infusion.

Effects of peripheral ganglionic blockers on icv CRF-enhanced startle (experiment 3). Because chlorisondamine effectively blocked the increased sympathetic outflow caused by icv CRF (Brown et al., 1982), and both chlorisondamine $(3 \mathrm{mg} / \mathrm{kg})$ and hexamethonium $(10 \mathrm{mg} / \mathrm{kg})$ attenuated CRF-induced alterations in grooming, feeding, and locomotion (Britton and Indyk, 1989), the effect of icv CRF $(1.0 \mu \mathrm{g})$ on startle in animals pretreated with hexamethonium $(10 \mathrm{mg} / \mathrm{kg})$ or chlorisondamine $(3 \mathrm{mg} / \mathrm{kg})$ was examined.

In a preliminary experiment, it was found that neither $10 \mathrm{mg} / \mathrm{kg}$ hexamethonium (Sigma) nor $3 \mathrm{mg} / \mathrm{kg}$ chlorisondamine (Ciba-Geigy) altered baseline levels of startle when testing was carried out from 60 to $120 \mathrm{~min}$ after injection. In the main experiment, icv cannulas were implanted in two groups of naive animals. Eighteen rats received intraperitoneal injections of saline $(n=8)$ or $10 \mathrm{mg} / \mathrm{kg}$ hexamethonium hydrochloride dissolved in saline $(n=10)$, and a second group of 10 rats received intraperitoneal injection of either distilled water $(n=5)$ or $3 \mathrm{mg} / \mathrm{kg}$ chlorisondamine dissolved in distilled water $(n=5)$. Intraperitoneal injections were administered in a $1 \mathrm{ml} / \mathrm{kg}$ volume $10 \mathrm{~min}$ before the rats were placed into the test cages. All rats were tested for startle for $30 \mathrm{~min}$ and then remotely infused with $1.0 \mu \mathrm{g} \mathrm{CRF}$ and tested, as previously described.

Effects of the CRF antagonist $\alpha$ hCRF given prior to or following administration of icv CRF (experiment 4). Swerdlow et al. (1989) found that pretreatment with the CRF antagonist $\alpha \mathrm{hCRF}$ blocked the excitatory effects of CRF on startle without having any significant effect on baseline startle. In that study, however, the total duration of the test session was $12 \mathrm{~min}$. Because the excitatory effects of CRF in the present study were measured for a much longer period of time, the effects of the CRF antagonist $\alpha \mathrm{hCRF}$, when given either prior to or 90 min after infusion of $C R F$, were evaluated.

To evaluate the effects of $\alpha \mathrm{hCRF}$ given prior to CRF, a total of 38 rats were used. All rats were given the usual $30 \mathrm{~min}$ preinfusion baseline and then removed from the startle test cages and infused with either ACSF or $\alpha$ hCRF ( 25 or $50 \mu \mathrm{g}$ ) followed $5 \mathrm{~min}$ later by a second infusion of either ACSF or CRF $(1 \mu \mathrm{g})$. This created six groups: ACSF-ACSF $(n$ $=7), \alpha \mathrm{hCRF}(25 \mu \mathrm{g})-\operatorname{ACSF}(n=6), \alpha \mathrm{hCRF}(50 \mu \mathrm{g})-\operatorname{ACSF}(n=6), \mathrm{ACSF}-$ $\mathrm{CRF}(n=7), \alpha \mathrm{hCRF}(25 \mu \mathrm{g})$-CRF $(n=7)$, and $\alpha \mathrm{hCRF}(50 \mu \mathrm{g})-\mathrm{CRF}(n$ $=6$ ). Immediately after the second infusion, the animals were returned to the startle test cages and presented with the first of 240 startle stimuli over $120 \mathrm{~min}$

To evaluate the effects of $\alpha$ hCRF given after CRF, icv cannulas were implanted in 20 more rats. They were given the usual $30 \mathrm{~min}$ baseline test, removed from the test chamber, infused with $1 \mu \mathrm{g}$ of CRF, returned to the test chamber, and presented with the first of 180 startle stimuli over $90 \mathrm{~min}$. After the last startle stimulus they were removed from the test chamber, infused with either $\operatorname{ACSF}(n=5)$ or $50 \mu \mathrm{g} \alpha \mathrm{hCRF}$, returned to the test chamber, and presented with an additional 180 startle stimuli over $90 \mathrm{~min}$.

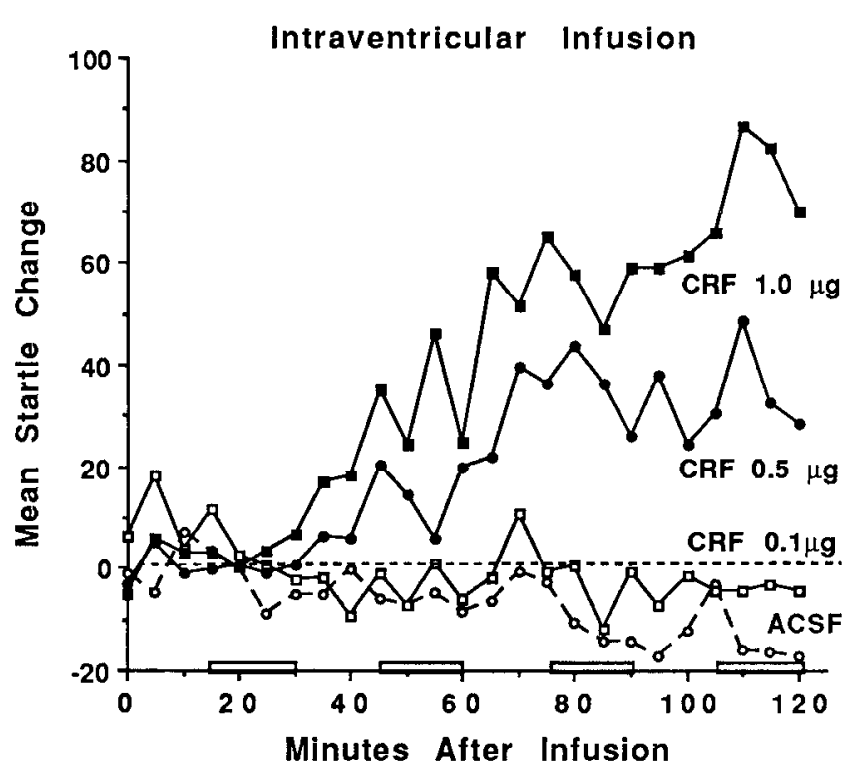

Figure 1. Mean startle change scores of rats receiving icv infusion of ACSF or CRF $(0.1,0.5$, and $1.0 \mu \mathrm{g})$. The rectangular boxes on the $\mathrm{x}$-axis bracket are the four time periods sampled for statistical analyses.

\section{Results}

Dose-response effects of icv CRF on startle amplitude (experiment 1). A one-way ANOVA on the preinfusion baseline data revealed no significant differences in the preinfusion mean baseline startle scores of the various groups. This was also true for each of the other experiments. Therefore, hereafter the mean startle change scores will be used for all data presentation and statistical analyses. Figurc 1 shows that icv infusion of CRF caused a dose-dependent enhancement of acoustic startle such that $0.1 \mu \mathrm{g}$ was ineffective, $1.0 \mu \mathrm{g}$ caused a marked effect, and $0.5 \mu \mathrm{g}$ caused an intermediate effect. The enhancement began approximately $30 \mathrm{~min}$ after infusion, grew over time, and persisted to the end of the session. Startle scores of the $0.5 \mu$ group reached asymptote at a value close to double that of baseline startle (range, approximately 20-60 units), showing about 40 units of increase, while those of the $1.0 \mu \mathrm{g}$ group reached a value almost triple the baseline startle resulting in an increase of 7080 units.

A $4 \times 4$ (dose $\times$ period) repeated-measures ANOVA was performed with dose as a between-subjects variable and period as a within-subjects variable. There was a significant effect of dose $[F(3,17)=12.49 ; p<0.001]$, which was linearly related to the amount of CRF infused $[F(1,17)=35.93 ; p<0.001]$. There was also a significant pcriod effect $[F(3,51)=8.59 ; p<$ $0.001]$, indicating an overall increase in startle amplitude with time, and a dose $\times$ period interaction $[F(9,51)=5.95 ; p<$ $0.001]$. Post hoc analyses comparing the ACSF group to groups receiving different doses of CRF found that, while no amount of CRF enhanced startle at period $1,0.5 \mu \mathrm{g}$ or $1.0 \mu \mathrm{g}$ CRF caused significant enhancement at periods 2-4 [i.e., from about 35 to 120 min after infusion; for the $0.5 \mu \mathrm{g}$ group: $F(1,17)=5.08$, $10.76,9.89$, respectively; $p<0.05$; for the $1.0 \mu$ group: $F(1,17)$ $=14.60,21.22,30.90$, respectively; $p<0.001$; Fig. 1].

When $10 \mu \mathrm{g}$ of CRF were infused, the results were considerably more complex. Animals that received $10 \mu \mathrm{g}$ of CRF on their first day of the crossover design showed little or no change in startle. In contrast, rats that received CRF on the second day 

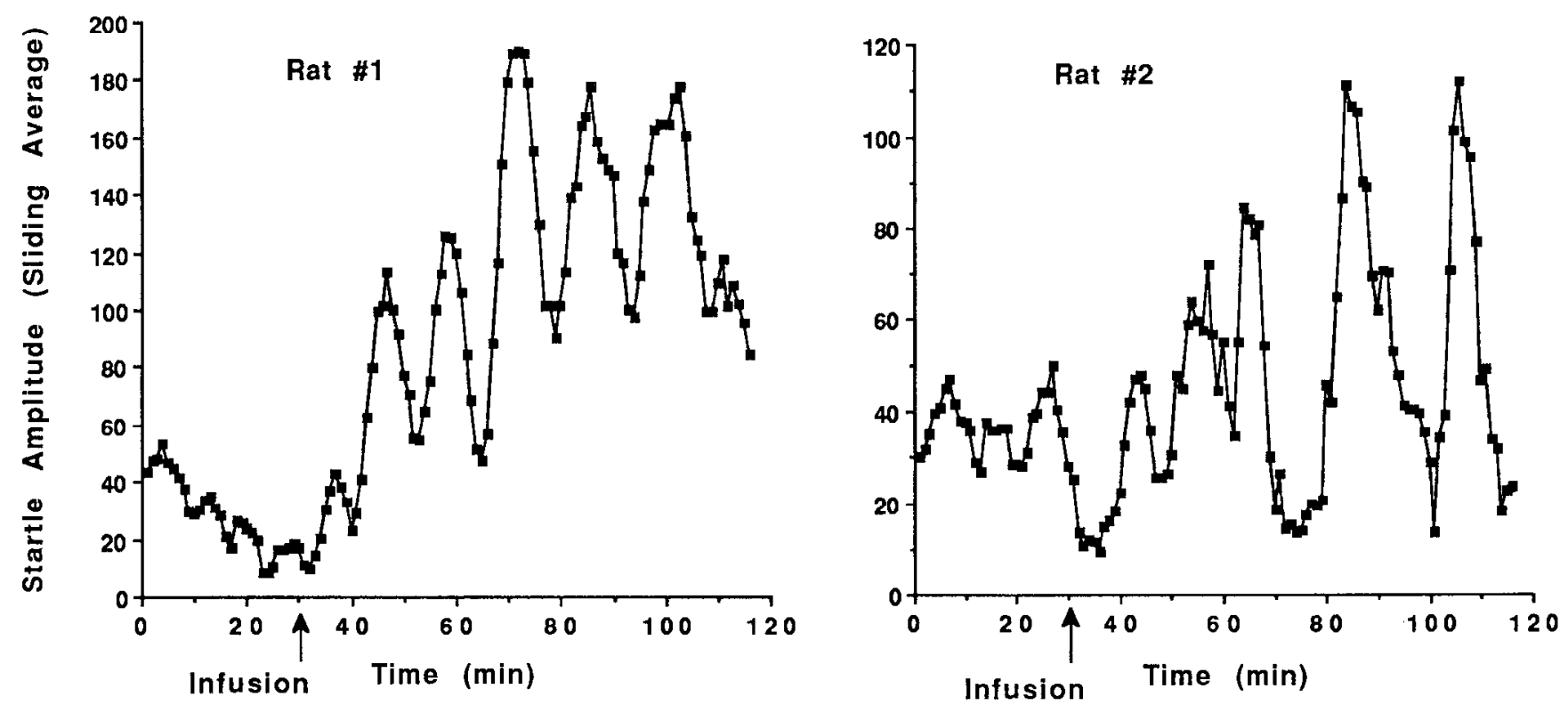

Figure 2. Example of two rats displaying marked oscillatory patterns of startle facilitation and inhibition after icv infusion of $10 \mu \mathrm{g}$ CRF.

of the crossover design (i.e., $2 \mathrm{~d}$ after infusion of ACSF) showed very large elevations in startle. However, the increase in startle oscillated markedly over time. At times startle in the CRFinfused animals was so high that it was at the ceiling of the measurement system. At other times, startle levels returned to basal or even subbasal values.

To bring out this oscillatory pattern, the change scores for animals receiving $10 \mu \mathrm{g}$ of CRF on the second day of the crossover design were submitted to a sliding average using a cycle of five successive blocks of five stimuli, a method used often to bring out cyclic variations. Figure 2 shows an example of two animals that had the most obvious oscillatory pattern after this high dose of CRF. In both rats, the oscillatory pattern was evident about 30-40 min after infusion and persisted until the end of the test session. In rat 1 , the time between the peaks of startle facilitation was about $11-12 \mathrm{~min}$; in rat 2, about $20 \mathrm{~min}$. Similar oscillatory patterns were seen in the other three rats, with interpeak intervals of approximately $18-20 \mathrm{~min}$. In contrast to these results, infusion of $1 \mu \mathrm{g}$ CRF did not produce these prominent oscillations in startle amplitude even in animals that showed very large increases in startle amplitude after CRF.

The interaction between icv CRF-enhanced startle and stimulus repetition (experiment 2). Figure 3 shows the results when CRF or ACSF was infused and rats were returned to their home cages with no intervening startle stimuli. For comparison, the data for the group given $1 \mu \mathrm{g}$ of CRF and then tested immediately thereafter (experiment 1 ) are also shown.

The delayed excitatory effect of icv CRF on startle did not result from an increase in sensitization caused by repetitive presentation of the startle eliciting stimuli. Thus, rats infused with CRF but then returned to their home cages and not presented with startle stimuli had high levels of startle as soon as testing began $1 \mathrm{hr}$ later compared to their scores after infusion of $\operatorname{ACSF}[F(1,9)=28.29 ; p<0.001]$. After testing began, startle showed a rapid decline in amplitude in both the CRF-delay and ACSF-delay groups, reflecting habituation caused by the introduction of repetitive startle stimuli. Under these test conditions, the rate of habituation was comparable in the CRF-delay and ACSF-delay groups and there was no significant drug $\times$ time interaction $(F<1)$.

When the two groups given CRF are compared, the CRFdelay group had the highest level of startle at the $1 \mathrm{hr}$ time point, which then quickly habituated to the level of the CRF-no delay group. These latter data suggest that the CRF-no delay group had probably reached an asymptotic level of habituation produced by the startle stimuli that were presented after CRF infusion, even though their net change in startle still increased as CRF progressively elevated startle. On the other hand, the CRFdelay group presumably should have had much less habituation prior to testing (i.e., only that produced by the preinfusion testing), so that their initial test scores would reflect the excitatory effect of CRF on startle at this time point, unopposed by habituation. The advent of repetitive startle stimuli then produced asymptotic habituation in this group as well, leading to scores that were equivalent to those in the CRF-no Delay group. Taken together, all of these data indicate that CRF-enhanced startle does not appear to result from an increased sensitization to stimulus repetition or from a blockade of habituation.

Finally, in the group that received additional test sessions, CRF-enhanced startle was still clearly evident $6 \mathrm{hr}$ after infusion, the latest time point tested (data not shown). However, startle levels were normal when testing occurred $24 \mathrm{hr}$ after infusion. Thus, the effect of icv CRF on startle lasts at least 6 $\mathrm{hr}$, but then returns to baseline sometime within $24 \mathrm{hr}$.

Effects of peripheral ganglionic blockers on icv CRF-enhanced startle (experiment 3). Figure 4 shows that in saline-pretreated rats, icv CRF produced enhancement of startle that increased over the test session. In hexamethonium-pretreated rats, CRF seemed to produce a less pronounced effect. These data were analyzed using a $2 \times 4$ (pretreatmen $\times$ period) repeated-measure ANOVA, with pretreatment (hexamethonium, saline) as a between-subjects variable and period as a within-subjects variable. This showed a significant effect of period $[F(3,48)=16.61$; $p<0.001$ ], indicating an increase in startle amplitude across 


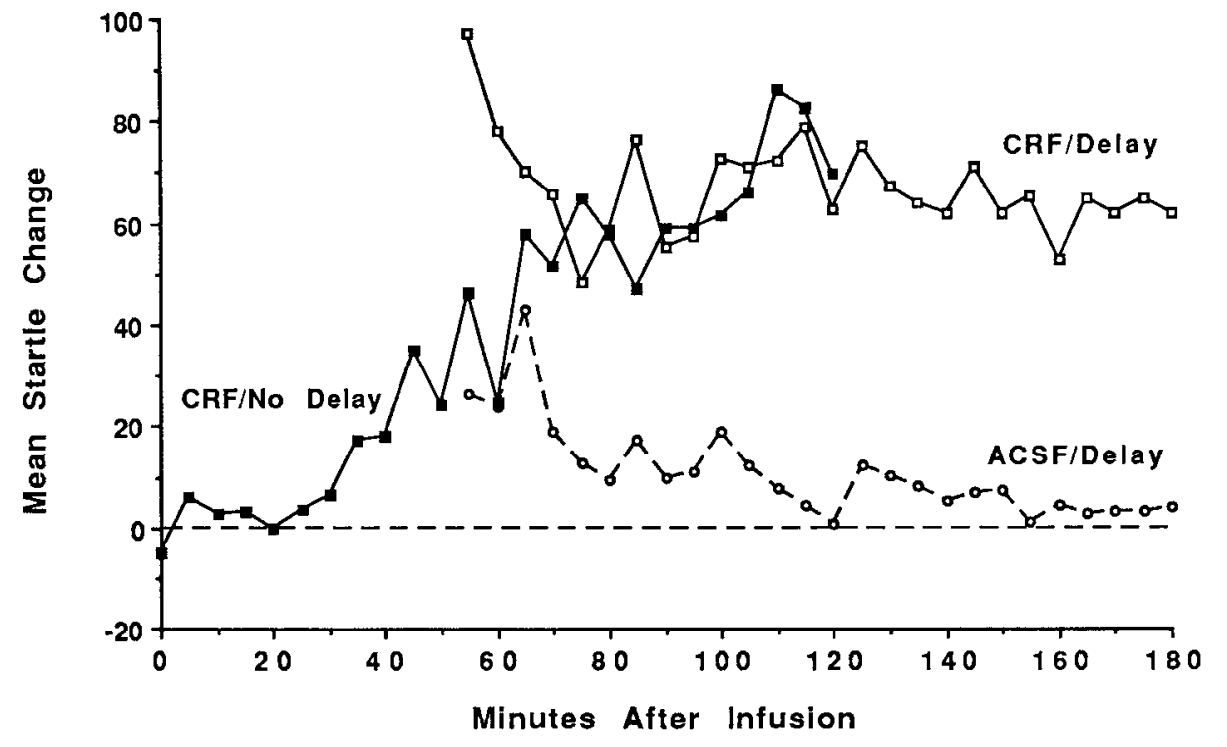

Figure 3. Mean startle change scores of rats receiving icv infusion of ACSF or CRF $(1.0 \mu \mathrm{g})$ when testing was delayed for $1 \mathrm{hr}$ after infusion. For comparison, the data from experiment 1 , where rats were infused with $1 \mu \mathrm{g}$ of CRF and then tested immediately after infusion, arc also shown. the session. However, the pretreatment effect only approached statistical significance $[F(1,18)=3.12 ; p<0.10]$ and the pretreatment $\times$ period interaction was not significant $(F<1)$.

Similar results were obtained for rats pretreated with chlorisondamine (Fig. 4). In water-pretreated rats, icv administration of CRF produced the typical enhancement of startle. Chlorisondamine did not affect the early stage of this effect but seemed to suppress the enhancing effect at later stages, such that chlorisondamine-pretreated rats showed increased startle comparable to the water-pretreated controls at periods 1 and 2 , but tended to reach a lower asymptotic value at periods 3 and 4 (Fig. 4). ANOVA found a significant effect of period $[F(3,24)=$ $16.22 ; p<0.001$ ], reflecting the fact that the magnitude of CRFenhanced startle increased over time. However, once again, the pretreatment factor (chlorisondamine vs. water) was not signif- icant $[F(1,8)=2.61 ; p<0.15]$, nor was the pretreatment $\times$ period interaction $(F<1.0)$.

Because both analyses indicated that the attenuating effect of ganglionic blockers approached statistical significance, data from the two experiments were pooled. A $2 \times 4$ (pretreatment $\times$ period) ANOVA performed on these pooled data showed a significant effect of pretreatment $[F(1,28)=4.69 ; p<0.05]$. Further analyses revealed that the difference between the ganglionic blockers and saline at period 4 was significant $[F(1,28)$ $=6.39 ; p<0.02$ ]. These findings suggest that peripheral feedback from sympathetic activation may contribute to the startleenhancing effect of icv CRF, particularly at the later phase. However, this contribution appears modest, at least with respect to the two drugs and doses used here to address this question.

Effects of the CRF antagonist $\alpha$ hCRF given prior to or follow-
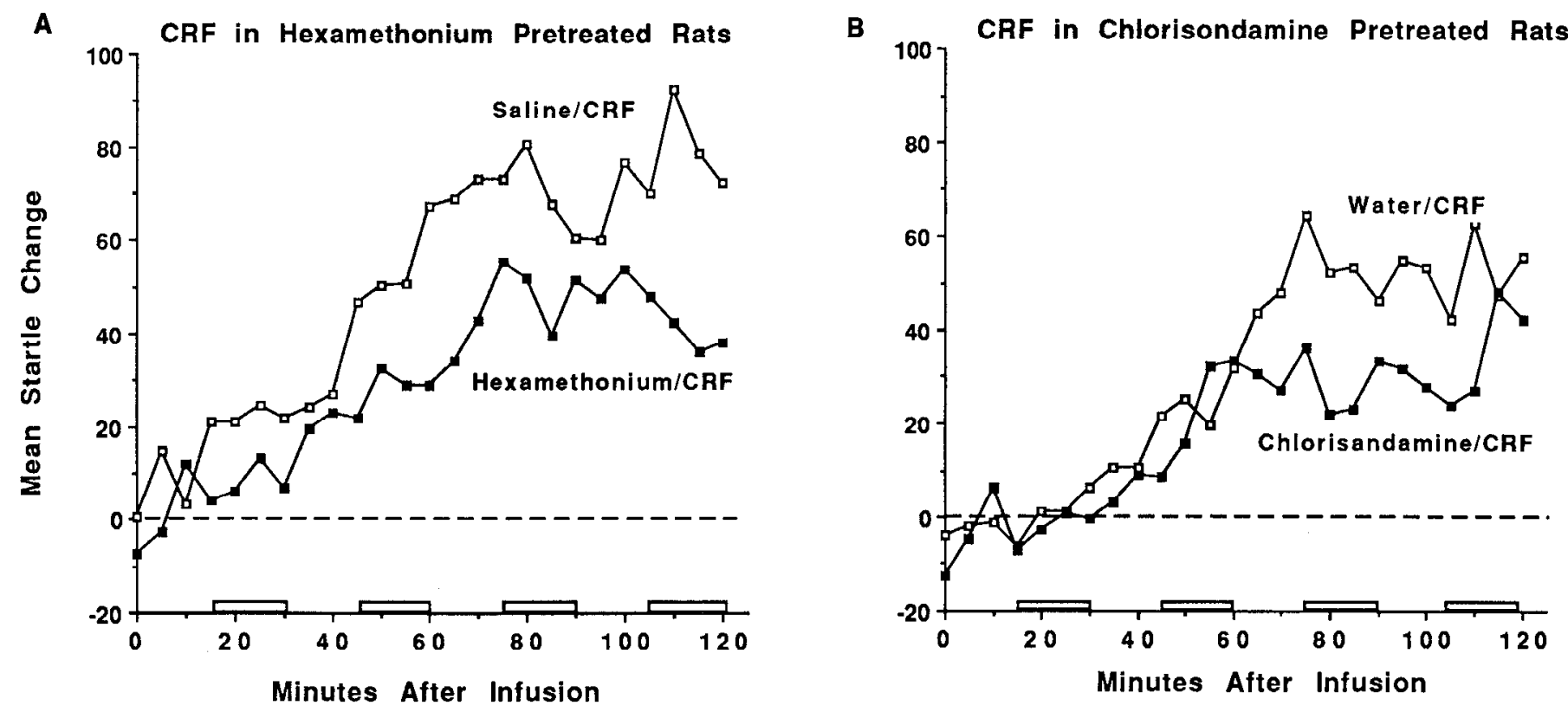

Figure 4. Mean startle change scores following infusion of CRF $(1 \mu \mathrm{g})$ of rats pretreated $45 \mathrm{~min}$ earlier with either saline or $10 \mathrm{mg} / \mathrm{kg}$ of hexamethonium $(A)$ or saline or $3 \mathrm{mg} / \mathrm{kg}$ chlorisondamine $(B)$. 


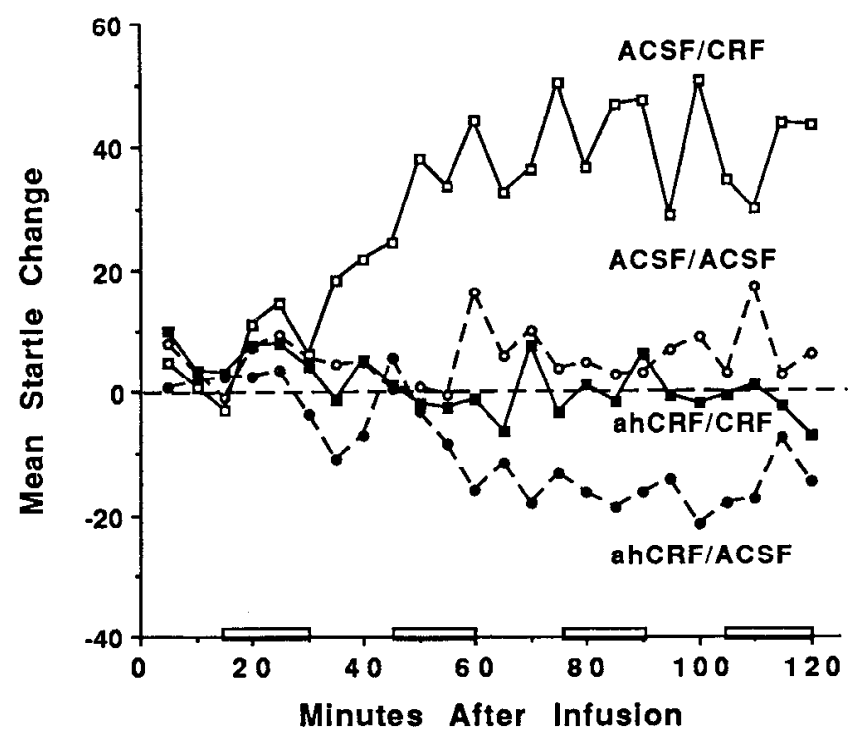

Figure 5. Mean startle change scores of rats pretreated 5 min earlier with either ACSF or $50 \mu \mathrm{g}$ of $\alpha \mathrm{hCRF}$ followed by a second infusion of either ACSF or $1 \mu \mathrm{g}$ CRF.

ing administration of $C R F$ (experiment 4). Figure 5 shows that $50 \mu \mathrm{g}$ of the CRF antagonist $\alpha \mathrm{hCRF}$ blocked the excitatory effect of $1 \mu \mathrm{g}$ CRF on startle throughout the $2 \mathrm{hr}$ test session.

To capture better the dose-response effects of $\alpha$ hCRF on both baseline startle and CRF-enhanced startle, Figure 6 shows summary data over the last block of test trials for animals given either ACSF or CRF following either 0,25 , or $50 \mu \mathrm{g} \alpha \mathrm{hCRF}$. An overall ANOVA of the time course data using drug (CRF vs. ACSF) and antagonist dose $(0,25$, or $50 \mu \mathrm{g}$ of $\alpha \mathrm{hCRF})$ as between-subjects variables and period after infusion as a withinsubjects variable found an overall effect of drug $[F(1,32)=13.19$; $p<0.001]$ and antagonist dose $[F(2,32)=9.53 ; p<0.001]$. More importantly, there was a significant drug $\times$ period interaction $[F(1,32)=12.28 ; p<0.001]$, reflecting the differential change in startle over time after ACSF versus CRF, as well as a significant antagonist dose $\times$ period interaction $[F(6,96)=$ $6.75 ; p<0.001]$, reflecting the fact that the depressant effect of different doses of $\alpha \mathrm{hCRF}$ became larger as the test session progressed.

Analysis of the data in Figure 6 shows that in rats tested with ACSF, $\alpha$ hCRF caused a dose-related depression of startle $[F(2,16)$ $=5.69 ; p<0.01]$. Subsequent contrasts showed that the $50 \mu \mathrm{g}$ $\alpha$ hCRF group differed significantly from both the ACSF group $[0 \mu \mathrm{g} ; F(1,16)=9.98 ; p<0.01]$ and the $25 \mu \mathrm{g}$ group $[F(1,16)$ $=7.03 ; p<0.02]$, which did not differ from each other. In rats tested with $\mathrm{CRF}, \alpha \mathrm{hCRF}$ also caused a dose-related depression of startle $[F(2,16)=8.64 ; p<0.01]$. Subsequent contrasts showed that the ACSF group $(0 \mu \mathrm{g})$ differed significantly from both the $25 \mu \mathrm{g}[F(1,16)=6.16 ; p<0.03]$ and the $50 \mu \mathrm{g} \alpha \mathrm{hCRF}$ groups $[F(1,16)=17.14 ; p<0.001]$, which did not differ significantly from each other.

Figure 7 shows the results when $50 \mu \mathrm{g}$ of $\alpha \mathrm{hCRF}$ was infuscd 90 min after infusion of $1 \mu \mathrm{g}$ CRF. Consistent with the previous data, icv infusion of CRF increased startle over the 90 min test session. Removal of the rats from the test cages and infusion of ACSF caused a temporary inhibition of startle that then returned to the previous CRF-elevated level in about 10-15 min. Infusion of $\alpha \mathrm{hCRF}$ caused a similar temporary depression of startle fol-

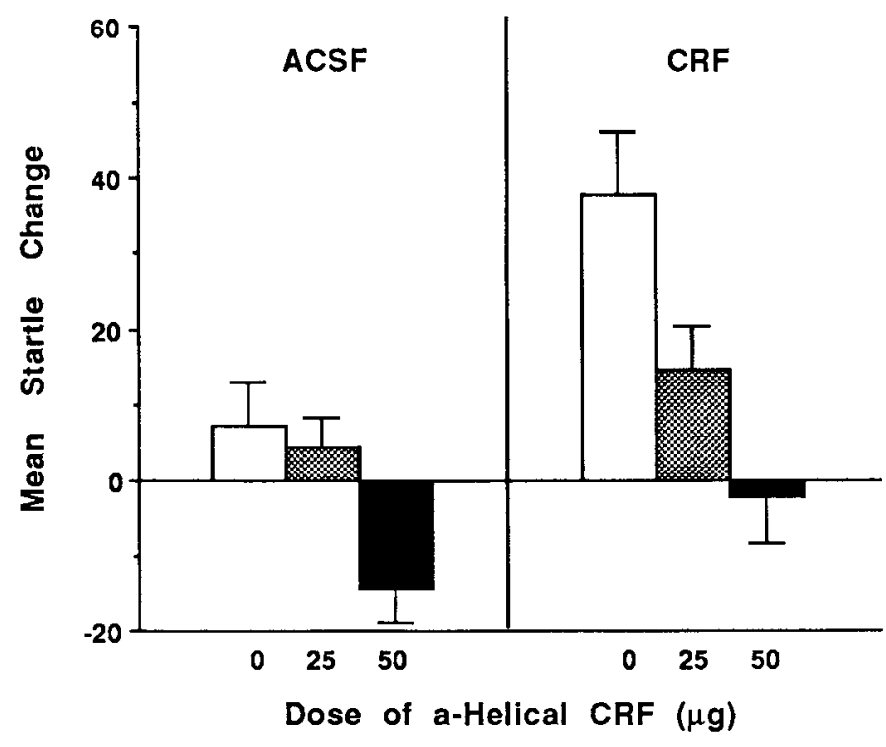

Figure 6. Mean startle change score following icv infusion of various doses of $\alpha \mathrm{hCRF}$ in rats infused $5 \mathrm{~min}$ later with either $1 \mu \mathrm{g}$ CRF or ACSF.

lowed by a much longer and profound reversal of the CRF effect, such that startle had essentially returned to its original baseline by $90 \mathrm{~min}$ after infusion of $\alpha \mathrm{hCRF}$.

Several ANOVAs were applied to these data. First, there was no significant difference between the two groups either in their baseline level of startle prior to CRF infusion or in the magnitude of the elevation of startle produced by CRF measured during the last $20 \mathrm{~min}$ of the $90 \mathrm{~min}$ post-CRF infusion period (both $F \mathrm{~s}<1$ ). Second, the greater decrease in startle during the 10 min period following infusion of $\alpha \mathrm{hCRF}$ versus ACSF was not significant $(F<1)$. On the other hand, analysis of data across periods 11-30, 41-60, and 71-90 min after infusion of $\alpha \mathrm{hCRF}$ or ACSF found significantly lower overall startle levels after infusion of $\alpha \mathrm{hCRF}$ versus ACSF. Subsequent contrasts showed that the $\alpha$ hCRF group had significantly lower levels of startlc than the ACSF group from 71 to $90 \mathrm{~min}$ after infusion $[F(1,18)=9.13 ; p<0.01]$ and from 41 to $60 \mathrm{~min}$ after infusion $[F(1,18)=6.13 ; p<0.02]$, but not from 11 to $30 \mathrm{~min}$ after infusion $[F(1,18)=2.38 ; p>0.1]$. Finally, paired $t$ tests showed a significant decrease in startle from the last block of trials prior to infusion of $\alpha \mathrm{hCRF}$ to the last block of trials postinfusion [ $t(9)$ $=3.11 ; p<0.01]$, but no significant decrease in startle in animals infused with ACSF. These data indicate that $\alpha \mathrm{hCRF}$ was still capable of reversing the excitatory effect on startle when CRF was given $90 \mathrm{~min}$ earlier, and that the development of this reversal became progressively larger between 80 and $90 \mathrm{~min}$ after infusion of $\alpha \mathrm{hCRF}$.

\section{Discussion}

The present study found that icv infusion of CRF produced a dose-dependent enhancement of the acoustic startle reflex. At $1 \mu \mathrm{g}$, CRF-enhanced startle began approximately $20-30 \mathrm{~min}$ after infusion, grew steadily to a maximum effect in about 80 $90 \mathrm{~min}$, and lasted for at least $6 \mathrm{hr}$. This delayed onset of CRFenhanced startle contrasts with earlier work which showed that icv CRF increased startle $5 \mathrm{~min}$ after infusion (Swerdlow et al., 1986). In view of the sensitivity of the CRF effect to external stress (Berridge and Dunn, 1987), the handling of the animal 


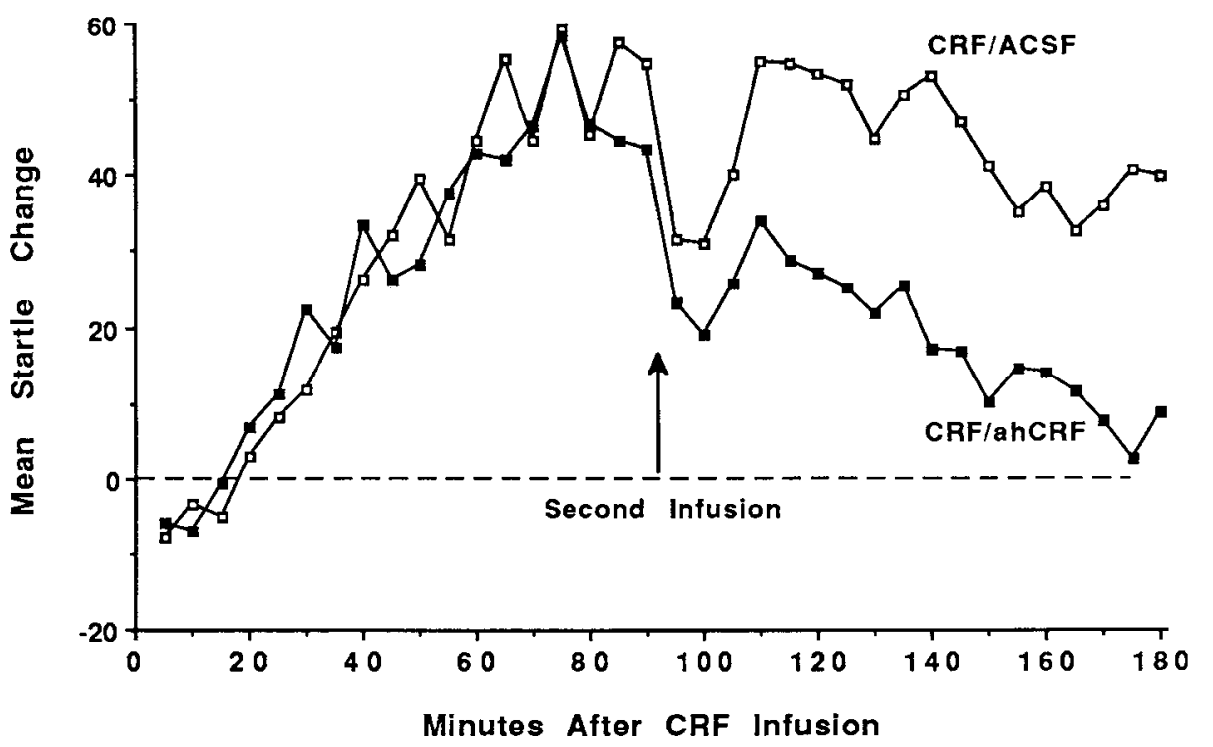

Figure 7. Mean startle change scores of rats infused with $1 \mu \mathrm{g}$ CRF followed $90 \mathrm{~min}$ later by a second infusion of either ACSF or $50 \mu \mathrm{g}$ of $\alpha \mathrm{hCRF}$. during the infusion procedure of Swerdlow et al. (1986) may have facilitated an early appearance of CRF-enhanced startle, compared to the remote infusion procedure used in the present experiment. However, experiment 4 involved removing the animal from the test chamber and infusing CRF, yet it still did not produce an elevation in startle within $5 \mathrm{~min}$ of infusion. Other differences in the test environments may thus account for this difference and will require further study.

In the design of these studies, CRF was infused and then startle was tested over the next $120 \mathrm{~min}$ by presenting startle stimuli every $30 \mathrm{sec}$. It was possible that the progressively larger effect of CRF over time resulted from an cnhancement of sensitization produced either by repetitive presentation of the startle stimuli or by exposure to the background noise in the test chamber, each of which can produce sensitization of the startle reflex (e.g., Groves and Thompson, 1970; Davis, 1974). This interpretation is unlikely in view of the finding that animals infused with CRF and then returned to the colony room with no intervening startle stimuli had very high levels of startle when testing began for the first time $60 \mathrm{~min}$ after CRF infusion. Moreover, other comparisons within that study indicated that CRF did not block habituation. Thus, the progressive elevation in startle following CRF infusion resulted from a progressive absorption of the drug to its relevant site of action or some other time-dependent effect initiated by CRF infusion.

Consistent with Swerdlow et al. (1986), a high dose of CRF $(10 \mu \mathrm{g})$ generally produced less of an excitatory effect than lower doses. Whilc nonmonotonic effects of peptides on behavior are well documented, the high-dose CRF data obtained in the present studies were quite remarkable. Using a crossover withinsubjects design, $10 \mu \mathrm{g}$ of CRF never elevated startle when it was given on day 1. However, when given on day 2 (i.e., after a previous infusion of ACSF plus 120 min of startle stimuli), CRF often produced dramatic increases in startle. Further, the startle facilitation showed a prominent oscillatory pattern, going back and forth from very high levels to very low levels with a period of 10-20 min. Visual observation throughout testing revealed that the animals remained almost motionless, so that the high levels of startle did not reflect seizure-induced movements picked up by the accelerometer and mistaken for startle. In fact, if CRF had produced proconvulsant electrical brain activity, this would probably tend to have depressed startle, because convulsants such as picrotoxin or pentylenetetrazol markedly depress startle (Gallager et al., 1983; M. Davis and D. W. Gallager, unpublished observations). Therefore, the prominent oscillatory pattern of startle modulation after high doses of CRF may reflect a generally high level of excitation interrupted periodically by proconvulsant activity (e.g., Ehlers et al., 1983; Weiss et al., 1986) that would inhibit startle and hence counter the expected excitatory effect. However, it is not clear how the relatively long time constant of startle oscillations $(10-20 \mathrm{~min})$ relates to the generally much shorter periods of oscillatory seizure activity.

It is conccivable that high doses of CRF activate other oscillatory systems that inhibit startle and have much longer time constants than seizure activity. In sheep, endogenous or stressactivated release of both CRF and arginine vasopressin is pulsatile in nature, with a period of 20-30 min (Engler et al., 1989). It is possible, therefore, that icv CRF at high doses interacts with endogenous, pulsatile release of CRF to activate peripheral hormonal systems (e.g., ACTH or corticosterone), which might interact with CRF-induced startle facilitation. Pulsatile release of these hormones, with time constants on the order of 10-20 min, might account for the oscillatory pattern of startle facilitation after high doses of CRF. Further studies looking at the effects of high doses of CRF on startle after hypophysectomy or systemic administration of dexamethasone or vasopressin antagonists might be used to test this hypothesis. Whatever the mechanism, CRF appears to be unique in this respect, because other drugs such as amphetamine, strychnine, rolipram, and 5-methoxy- $N$ - $N$-methyltryptamine markedly increase acoustic startle amplitude without producing these pronounced oscillatory effects, even at high doses (Davis et al., 1975, 1980; Kehne et al., 1981, 1991).

Peripheral autonomic reactions have been suggested to play a role in emotional behavior (Svensson, 1987). Chlorisondamine has been shown to block the increased sympathetic outflow caused by icv CRF (Brown et al., 1982), and both chlorisondamine $(3 \mathrm{mg} / \mathrm{kg})$ and hexamethonium $(10 \mathrm{mg} / \mathrm{kg})$ attenuated CRF-induced alterations in grooming, feeding, and locomotion (Britton and Indyk, 1989). At these doses, neither drug altered startle baseline yet each slightly attenuated the magnitude of CRF-enhanced startle, especially toward the end of the $120 \mathrm{~min}$ 
test session. However, the results were only significant when the results from both drug studies were combined and even then the overall attenuation was modest. Hence, peripheral sympathetic activation may play a partial role in CRF-enhanced startle, particularly at relatively long intervals after icv CRF infusion.

The long-lasting effect of CRF on startle is consistent with that demonstrated on locomotor behavior (Sutton et al., 1982) and suggests that icv CRF may occupy its receptor for a long time. In the present study, the CRF antagonist $\alpha$ hCRF was capable of reversing the CRF effect from 90 to 180 min after CRF infusion. On the other hand, one wonders whether exogenously administered CRF could still be present in the brain $180 \mathrm{~min}$ after infusion. As suggested by Ono et al. (1985), it is possible that CRF given icv might initiate a sequence of events that would lead to a long-lasting release of endogenous CRF. If endogenous CRF were responsible for the elevation in startle, this could explain how CRF-enhanced startle could be reversed by $\alpha$ hCRF long after an icv infusion of CRF. For example, icv $\mathrm{CRF}$ increases the firing rates of noradrenergic containing cells (Valentino et al., 1983; Valentino and Foote, 1987) and increases noradrenergic turnover (Dunn and Berridge, 1987; Matsuzaki et al., 1989; Butler et al., 1990). In turn, norepinephrine can increase the release of CRF from the paraventricular nucleus (Plotsky, 1987; Szafarczyk et al., 1987; Plotsky et al., 1989). Thus, icv CRF could release endogenous CRF from the paraventricular nucleus or from other brain areas containing CRF neurons via activation of noradrenergic neurons. CRF activates cells in the locus coeruleus rapidly after icv infusion (Valentino et al., 1983). Perhaps the time course of facilitation of startle reflects the time course of noradrenergic-induced CRF release. In fact, several behavioral effects of icv CRF can be blocked by the noradrenergic antagonist propranolol (cf. Dunn and Berridge, 1990), and preliminary evidence indicates that pretreatment with icv propranolol attenuates CR F-enhanced startle (K. C. Liang and M. Davis, unpublished observations). Currently, we are testing whether local infusion of noradrenergic antagonists into specific brain areas will block CRF-enhanced startle.

By itself a high dose of the CRF antagonist $\alpha$ hCRF given icv significantly depressed baseline levels of startle beginning about $60 \mathrm{~min}$ after infusion. This suggests that the stress of the present test procedures (e.g., handling, icv infusion, loud startle-eliciting stimuli, background noise) may facilitate startle via release of endogenous CRF, although nonspecific depressant effects of $\alpha$ hCRF on startle cannot be ruled out. The late onset of this depressant effect of $\alpha \mathrm{hCRF}$ on startle probably explains why this effect was not reported by Swerdlow et al. (1989), as they only tested for a short time after infusion of $\alpha$ hCRF. However, in that study they did report that $\alpha$ hCRF blocked fear-potentiated startle using an auditory conditioned stimulus. This, along with the many examples where $\alpha$ hCRF blocks effects of stress (see introductory remarks), raises the possibility that conditioned fear may result from a release of CRF and, more generally, that CRF antagonists might be effective anxiolytic compounds. Currently, we are testing the effects of $\alpha$ hCRF on fear-potentiated startle using either a visual or auditory conditioned stimulus under conditions that produce different levels of fear.

As yet, it is not known where CRF acts in the brain to produce enhancement of startlc. Wc have found that clcctrolytic lesions of the central nucleus of the amygdala, which has a high density of both CRF receptors and cell bodies, markedly attenuates CRF-enhanced startle (Liang et al., 1992). Hence, it is possible that C.RF may diffuse from the ventricle and activate cells in the amygdala, which is known to project directly to the acoustic startle pathway (Rosen et al., 1991) and to play an important role in startle modulation (Hitchcock and Davis, 1986; Rosen and Davis, 1988). However, thus far we have not been able to find any evidence that direct infusion of CRF into the amygdala elevates startle (Liang et al., 1992). Therefore, the amygdala appears to be a critical structure in the neural circuitry activated by CRF, but not the brain region that contains the primary CRF receptor required for startle facilitation. Interestingly, electrophysiological experiments have shown that CRF inhibits cells in the lateral septal area (Eberly et al., 1983; Siggins et al., 1985). Lesions of the medial and lateral septal nuclei elevate startle, and this effect is blocked by lesions of the central nucleus of the amygdala (Melia et al., 1991). CRF might act by inhibiting the lateral septal nucleus, which would elevate startle by disinhibition of the amygdala, accounting for the ability of lesions of the amygdala to block CRF-enhanced startle. Currently, we are testing whether infusion of CRF into other brain regions, such as the septal nuclei, which have CRF receptors and which project to the amygdala, will facilitate startle.

In summary, these results confirm and extend previous findings that CRF elevates the startle reflex. In the present study, the effect of CRF lasted for many hours and was not dependent on increased sensitization produced by the startle-eliciting stimulus or a blockade of habituation. Peripheral sympathetic activation only slightly accounts for this enhancing effect. The excitatory effects of CRF could be completely blocked by icv infusion of the CRF antagonist $\alpha \mathrm{hCRF}$ given before or $90 \mathrm{~min}$ after infusion of CRF, indicating that exogenously applied CRF either remains in the brain for a very long time after administration, or through a central site of action which may initiate a process that results in a long-lasting activation of endogenous CRF. Because a good deal is currently known about the acoustic startle pathway and the way in which startle is modulated by various neurotransmitter systems, CRF-enhanced startle may be especially useful for analyzing neural systems activated by CRF relevant to fear and stress.

\section{References}

Baldwin HA, Rassnick S, Rivier J, Koob GF, Britton KT (1991) CRF antagonist reverses the "anxiogenic" response to ethanol withdrawal in the rat. Psychopharmacology 103:227-232.

Berridge CW, Dunn AJ (1987) A corticotropin-releasing factor antagonist reverses the stress-induced changes of exploratory behavior in mice. Horm Behav 21:393-401.

Berridge CW, Dunn AJ (1989) Restraint-stress-induced changes in exploratory behavior appear to be mediated by norepinephrine-stimulated release of CRF. J Neurosci 9:3513-3521.

Bohmer G, Schmid K, Ramsbott M (1990) Effects of corticotropinreleasing factor on central respiratory activity. Eur J Pharmacol 182: 405-411.

Britton DR, Indyk E (1989) Effects of ganglionic blocking agents on behavioral responses to centrally administered CRF. Brain Res 478: 205-210.

Britton DR, Koob G, Rivier J, Vale W (1982) Intraventricular corticotropin-releasing factor enhances behavioral effects of novelty. Life Sci 31:363-367.

Britton KT, Morgan J, Rivier J, Vale W, Koob GF (1985) Chlordiazepoxide attenuates response suppression induced by corticotropinreleasing factor in the conflict test. Psychopharmacology 86:170-174.

Britton KT, Lee G, Dana R, Risch SC, Koob GF (1986) Activating and 'anxiogenic' effects of corticotropin-releasing factor are not in- 
hibited by blockade of the pituitary-adrenal system with dexamethasone. Life Sci 39:1281-1286.

Brown JS, Kalish HI, Farber IE (1951) Conditional fear as revealed by magnitude of startle response to an auditory stimulus. J Exp Psychol 41:317-328.

Brown M (1986) Corticotropin releasing factor: central nervous system site of action. Brain Res 399:10-14.

Brown MR, Fisher LA, Spiess J, Rivier C, Rivier J, Vale W (1982) Corticotropin releasing factor: actions on the sympathetic nervous system and metabolism. Endocrinology 111:928-931.

Brown MR, Fisher LA, Webb V, Vale WW, Rivier JE (1985) Corticotropin-releasing factor: a physiologic regulator of adrenal cpincphrine secretion. Brain Res 328:355-357.

Butler PD, Weiss JM, Stout JC, Nemeroff CB (1990) Corticotropinreleasing factor produces fear-enhancing and behavioral activating effects following infusion into the locus coeruleus. J Neurosci 10:176183.

Cassella JV, Davis M (1986) The design and calibration of a startle measurement system. Physiol Behav 36:377-383.

Chappell PB, Smith MA, Kilts CD, Bissette G, Ritchie J, Anderson C, Nemeroff CB (1986) Alterations in corticotropin-releasing factorlike immunoreactivity in discrete rat brain regions after acute and chronic stress. J Neurosci 6:2908-2914.

Cole BJ, Koob GF (1988) Propranolol antagonizes the enhanced conditioned fear produced by corticotropin-releasing factor. J Pharmacol Exp Ther 247:902-910.

Cole BJ, Koob GF (1989) Low doses of corticotropin-releasing factor potentiate amphetamine-induced stereotyped behavior. Psychopharmacology 99:27-33.

Cole BJ, Cador M, Stinus L, Rivier J, Vale W, Koob GF, LeMoal M (1990) Central administration of a CRF antagonist blocks the development of stress-induced behavioral sensitization. Brain Res 512: 343-346.

Cummings S, Elde R, Ells J, Lindall A (1983) Corticotropin-releasing factor immunoreactivity is widely distributed within the central nervous system of the rat: an immunohistochemical study. J Neurosci 3:1355-1368.

Davis M (1974) Sensitization of the rat startle response by noise. J Comp Physiol Psychol 87:571-581.

Davis M (1980) Neurochemical modulation of sensory-motor reactivity: acoustic and tactile startle reflexes. Neurosci Biobehav Rev 4: 241-263.

Davis M (1986) Pharmacological and anatomical analysis of fear conditioning using the fear-potentiated startle paradigm. Behav Neurosci 100:814-824.

Davis M (1989) Sensitization of the acoustic startle reflex by footshock. Behav Neurosci 103:495-503.

Davis M, Astrachan DI (1978) Conditioned fear and startle magnitude: effects of different footshock or backshock intensities used in training. J Exp Psychol [Anim Behav] 4:95-103.

Davis M, Svensson TH, Aghajanian GK (1975) Effects of $d$ - and $l$-amphetamine on habituation and sensitization of the acoustic startle response in rats. Psychopharmacology 43:1-11.

Davis M, Astrachan DI, Gendelman PM, Gendelman DS (1980) 5-Methoxy- $N, N$-dimethyltryptamine: spinal cord and brainstem mediation of excitatory effects on acoustic startle. Psychopharmacology 70:123-130.

DeSouza EB (1987) Corticotropin-releasing factor receptors in the rat central nervous system: characterization and regional distribution. $\mathbf{J}$ Neurosci 7:88-100.

DeSouza EB, Insel TR, Perrin MH, Rivier J, Vale WW, Kuhar MJ (1985) Corticotropin-releasing factor receptors are widely distributed within the rat central nervous system: an autoradiographic study. $\mathrm{J}$ Neurosci 5:3189-3203.

Dunn AJ, Berridge CW (1987) Corticotropin-releasing factor administration elicits a stress-like activation of cerebral catecholaminergic systems. Pharmacol Biochem Behav 27:685-691.

Dunn AJ, Berridge CW (1990) Physiological and behavioral responses to corticotropin-releasing factor administration: is CRF a mediator of anxiety or stress responses? Brain Res Rev 15:71-100.

Dunn AJ, File SE (1987) Corticotropin-releasing factor has an anxiogenic action in the social interaction test. Horm Behav 21:193-202.

Dunn AJ, Berridge CW, Lai YI, Yachabach TL (1987) CRF-induced excessive grooming behavior in rats and mice. Peptides 8:841-844.

Eberly LB, Dudley CA, Moss RL (1983) Iontophoretic mapping of corlicotropin-releasing factor (CRF) sensitive neurons in the rat forebrain. Peptides 4:837-841.

Ehlers CL, Henriksen SJ, Wang M, Rivier J, Vale W, Bloom FE (1983) Corticotropin releasing factor produces increases in brain excitability and convulsive seizures in rats. Brain Res 278:332-336.

Engler D, Pham T, Fullerton MJ, Ooi G, Funder JW, Clarke IJ (1989) Studies of the secretion of corticotropin-releasing factor and arginine vasopressin into the hypophysial-portal circulation of the conscious sheep. Neuroendocrinology 49:367-381

Fellman D, Bugnon C, Bresson JL, Gouget A, Cardot J, Clavequin MC, Hadjiyiassemis M (1984) The CRF neuron: immunocytochemical study. Peptides 5:19-33.

Fisher LA (1989) Corticotropin-releasing factor: endocrine and autonomic integration of responses to stress. Trends Pharmacol Sci 10: 189-192.

Foote SL, Cha CI (1988) Distribution of corticotropin-releasing factorlike immunoreactivity in brainstem of two monkey species (Saimiri sciureus and Macaca fascicularis): an immunohistochemical study. J Comp Neurol 276:239-264.

Gallager DW, Kehne JH, Wakeman EA, Davis M (1983) Developmental changes in pharmacological responsivity of the acoustic startle reflex: effects of picrotoxin. Psychopharmacology 79:87-93.

Grillon C, Ameli R, Woods SW, Merikangas K, Davis M (1991) Fearpotentiated startle in humans: effect of anticipatory anxiety on the acoustic blink reflex. Psychophysiology 28:588-595.

Grosskrcutz CL, Brody MJ (1988) Rcgional hemodynamic responses to central administration of corticotropin-releasing factor (CRF). Brain Res 442:363-367.

Groves PM, Thompson RF (1970) Habituation: a dual process theory. Psychol Rev 77:419-450.

Haas DA, George SR (1988) Single or repeated mild stress increases synthesis and release of hypothalamic corticotropin-releasing factor. Brain Res 461:230-237.

Hitchcock JM, Davis M (1986) Lesions of the amygdala, but not of the cerebellum or red nucleus, block conditioned fear as measured with the potentiated startle paradigm. Behav Neurosci 100:11-22.

Imaki T, Nahan JL, Rivier C, Sawchenko PE, Vale W (1991) Differential regulation of corticotropin-releasing factor $\mathrm{mRNA}$ in rat brain regions by glucocorticoids and stress. J Neurosci 11:585-599.

Joscph S, Knigge KM (1983) Corticotropin-rclcasing factor: immunocytochemical localization in rat brain. Neurosci Lett 35:135-141.

Kalin NH, Sherman JE, Takahashi LK (1988) Antagonism of endogenous CRH systems attenuates stress-induced freezing behavior in rats. Brain Res 457:130-138.

Kehne JH, Gallager DW, Davis M (1981) Strychnine: brainstem and spinal mediation of excitatory effects on acoustic startle. Eur J Pharmacol 76:177-186.

Kehne JH, Boulis NM, Davis M (1991) Effects of the phosphodiesterase inhibitor rolipram on the acoustic startle response in rats. Psychopharmacology 105:27-36.

Koob GF, Bloom FE (1985) Corticotropin-releasing factor and behavior. Peptides 44:260.

Krahn DD, Gosnell BA, Levine AS, Morley JE (1988) Behavioral effects of corticotropin-rclcasing factor: localization and characterization of central effects. Brain Res 443:63-69.

Lang PJ, Bradley MM, Cuthbert BN (1990) Emotion, attention, and the startle reflex. Psychol Rev 97:377-395.

Lee EHY, Tsai MJ (1989) The hippocampus and amygdala mediate the locomotor stimulating effects of corticotropin releasing factor in mice. Behav Neural Biol 51:412-423.

Liang KC, Lee EHY (1988) Intra-amygdala injections of corticotropinreleasing factor facilitate inhibitory avoidance learning and reduce exploratory behavior in rats. Psychopharmacology 96:232-236.

Liang KC, Melia KR, Campeau S, Falls WA, Miserendino MJD, Davis $M$ (1992) Lesions of the central nucleus of the amygdala, but not the paraventricular nucleus of the hypothalamus, block the excitatory effects of corticotropin-releasing factor on the acoustic startle reflex. J Neurosci 12:2313-2320.

Matsuzaki I, Takamatsu Y, Moroji T (1989) The effects of intracerebroventricularly injected corticotropin-releasing factor (CRF) on the central nervous system: behavioral and biochemical studies. Neuropeptides 13:147-155.

Melia KR, Duman RS (1991) Involvement of corticotropin-releasing factor in chronic stress regulation of the brain noradrenergic system. Proc Natl Acad Sci USA 88:8382-8386. 
Melia KR, Sananes CB, Davis M (1991) Lesions of the central nucleus of the amygdala block the excitatory effects of septal ablation on the acoustic startle reflex. Physiol Behav 51:175-180.

Merchenthaler I (1984) Corticotropin-releasing factor (CRF)-like immunoreactivity in the rat central nervous system. Extrahypothalamic distribution. Peptides 5:53-69.

Ono N, DeCastro JCB, McCann SM (1985) Ultrashort-loop positive feedback of corticotropin (ACTH)-releasing factor to enhance ACTH in stress. Proc Natl Acad Sci USA 82:3528-3531.

Paxinos G, Watson C (1986) The rat brain in stereotaxic coordinates. Orlando, FL: Academic.

Plotsky PM (1987) Facilitation of immunoreactive corticotropin-releasing factor secretion into the hypophysial-portal circulation after activation of catecholaminergic pathways or central norepinephine injection. Endocrinology 121:924-930.

Plotsky PM, Cunningham ET, Widmaier EP (1989) Catecholaminergic modulation of corticotropin-releasing factor and adrenocorticotropin secretion. Endocrinol Kev 10:437-458.

Rivest S, Richard D (1990) Involvement of corticotropin-releasing factor in the anorexia induced by exercise. Brain Res Bull 25:169172.

Rivier C, Rivier J, Vale W (1986) Stress-induced inhibition of reproductive functions. Role of endogenous corticotropin-releasing factor. Science 231:607-609.

Rosen JB, Davis M (1988) Enhancement of acoustic startle by electrical stimulation of the amygdala. Behav Neurosci 102:195-202.

Rosen JB, Hitchcock JM, Sananes CB, Miserendino MJD, Davis M (1991) A direct projection from the central nucleus of the amygdala to the acoustic startle pathway: anterograde and retrograde tracing studies. Behav Neurosci 105:817-825.

Sakanaka M, Shibasaki T, Lederis K (1986) Distribution and efferent projections of corticotropin-releasing factor-like immunoreactivity in the rat amygdaloid complex. Brain Res 382:213-238.

Shibasaki T, Yamauchi N, Kato Y, Masuda A, Imaki T, Hotta M, Demura H, Oono H, Ling N, Shizume K (1988) Involvement of corticotropin-releasing factor in restraint stress-induced anorexia and reversion of the anorexia by somatostatin in the rat. Life Sci 43:11031110.

Siggins GR, Gruol D, Aldenhoff J, Pittman Q (1985) Electrophysiological actions of corticotropin-releasing factor in the central nervous system. Fed Proc 44:237-242.

Sirinathsinghji DJS, Heavens RP (1989) Stimulation of GABA release from the rat neostriatum and globus pallidus in vivo by corticotropinreleasing factor. Neurosci Lett 100:203-209.

Skofitsch G, Jacobowitz DM (1985) Distribution of corticotropinreleasing factor-like immunoreactivity in the rat brain by immunohistochemistry and radioimmunoassay: comparison and characterization of ovine and rat/human CRF antisera. Peptides 6:319-336.

Spadaro F, Berridge CW, Baldwin HA, Dunn A (1990) Corticotropinreleasing factor acts via a third ventricle site to reduce exploratory behavior in rats. Pharmacol Biochem Behav 36:305-309.

Stephens RJ Jr, Yang H, Rivier J, Tache Y (1988) Intracisternal injection of CRF antagonist blocks surgical stress-induced inhibition of gastric secretion in the rat. Peptides 9:1067-1070.

Sutton RE, Koob GF, LeMoal M, Rivier J, Vale W (1982) Corticotropin-releasing factor produces behavioural activation in rats. Nature 297:331-333.
Svensson TH (1987) Peripheral, autonomic regulation of locus coeruleus noradrenergic neurons in brain: putative implications for psychiatry and psychopharmacology. Psychopharmacology 92:1-7.

Swanson LW, Sawchenko PE, Rivier J, Vale WW (1983) Organization of ovine corticotropin-releasing factor immunoreactive cells and fibers in the rat brain: an immunohistochemical study. Neuroendocrinology 36:165-186.

Swerdlow NR, Geyer MA, Vale WW, Koob GF (1986) Corticotropinreleasing factor potentiates acoustic startle in rats: blockade by chlordiazepoxide. Psychopharmacology 88:147 152.

Swerdlow NR, Britton KT, Koob GF (1989) Potentiation of acoustic startle by corticotropin-releasing factor (CRF) and by fear are both reversed by $\alpha$-helical CRF (9-41). Neuropsychopharmacology 2:285292.

Szafarczyk A, Malaval F, Laurent A, Gibaud R, Assenmacher I (1987) Further evidence for a central stimulatory action of catecholamines on adrenocorticotropin release in the rat. Endocrinology 121:883892.

Tache Y, Goto Y, Gunion MW, Vale W, Rivier J, Brown M (1983) Inhibition of gastric acid secretion in rats by intracerebral injection of corticotropin-releasing factor. Science 222:935-937.

Takahashi LK, Kalin NH, VandenBurgt JA, Sherman JE (1989) Corticotropin-releasing factor modulates defensive-withdrawal and exploratory behavior in rats. Behav Neurosci 103:648-654.

Takahashi LK, Kalin NH, Baker EW (1990) Corticotropin-releasing factor antagonist attenuates defensive-withdrawal behavior elicited by odors of stressed conspecifics. Behav Neurosci 104:386-389.

Vale WW, Speiss J, Rivier C, Rivier J (1981) Characterization of a 41-residue ovine hypothalamic peptide that stimulates secretion of corticotropin and $\beta$-endorphin. Science 213:1394-1397.

Valentino R, Foote SL (1988) Corticotropin-releasing hormone increases tonic but not sensory-evoked activity of noradrenergic locus coeruleus neurons in unanesthetized rats. J Neurosci 8:1016-1025.

Valentino RJ, Foote SJ (1987) Corticotropin-releasing factor disrupts sensory responses of brain noradrenergic neurons. Neuroendocrinology 45:28-36.

Valentino RJ, Foote SI, Aston-Jones G (1983) Corticotropin-releasing factor activates noradrenergic neurons of the locus coeruleus. Brain Res 270:363-367.

Veldhuis HD, DeWied D (1984) Differential behavioral actions of corticotropin-releasing factor (CRF). Pharmacol Biochem Behav 21: 707-713.

Weiss GT, Davis M (1976) Automated system for acquisition and reduction of startle response data. Pharmacol Biochem Behav 4:713720.

Weiss SRB, Post RM, Gold PW, Chrousos G, Sullivan TL, Walker D, Pert A (1986) CRF-induced seizures and behavior: interaction with amygdala kindling. Brain Res 372:345-351.

Winslow JT, Newman JD, Insel TR (1989) CRH and $\alpha$-helical-CRH modulate behavioral measures of arousal in monkeys. Pharmacol Biochem Behav 32:919-926.

Yang XM, Dunn AJ (1990) Central $\beta_{1}$-adrenergic receptors are involved in CRF-induced defensive withdrawal. Pharmacol Biochem Behav 36:847-851.

Yang XM, Gorman AL, Dunn AJ (1990) The involvement of central noradrenergic systems and corticotropin-releasing factor in defensivewithdrawal behavior in rats. J Pharmacol Exp Ther 255:1064-1070. 